\title{
Reliability of fourier transform infrared spectroscopy in the characterization of human skin
}

\author{
Maria O. Longas ${ }^{1 *}$, Kenya Cheairs ${ }^{1}$, Michelle M. Puchalski ${ }^{1}$, Jung I. Park ${ }^{2}$
}

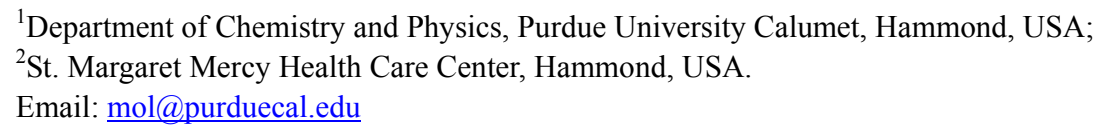

Received 24 June 2011; revised 3 July 2011; accepted 5 August 2011.

\begin{abstract}
Fourier transform infrared (FT-IR) spectroscopy, an organic molecule characterizing tool, is used here to differentiate young ( $36 \pm 2.87$ years) and aged (78 \pm 1.25 years) skins, based on glycosaminoglycan (GAG) and protein functional groups. Female breast mastectomy-skin, FT-IR spectroscopy revealed intensity differences that were quantified on GAG and protein standard curves, and assigned to the corresponding functional groups. Band intensity reductions at 78years include: $34.37 \%(\mathrm{w} / \mathrm{w})\left[1259-1223 \mathrm{~cm}^{-1}\right.$, sulfate $\left(\mathrm{SO}_{4}{ }^{2-}\right)$ /sulfonate $\left(\mathrm{SO}_{3}{ }^{-}\right) \mathrm{S}=\mathrm{O} / \mathrm{phosphate}\left(\mathrm{PO}_{4}{ }^{2-}\right)$ $P=0$ stretch]; $32.00 \%(w / w)\left(1383-1262 \mathrm{~cm}^{-1}\right.$, GAGmethyl C-H/C-C-H); and 35.60\% (w/w) [1738 - 1646 $\mathrm{cm}^{-1}, \mathrm{C}=\mathrm{O}$ stretch: $N$-acetylated GAG's, Amide I, and others]. Intensity increments at $\mathbf{7 8}$-years are $\mathbf{6 3 . 3 2 \%}$ (w/w) (1636 - $1523 \mathrm{~cm}^{-1}$, Phe/Trp/Tyr-C=C, Amide II); $27.02 \%(w / w)\left[1511-1457 \mathrm{~cm}^{-1}\right.$, protein $\delta\left(\mathrm{CH}_{2}\right) /$ $\delta\left(\mathrm{CH}_{3}\right)$ stretch]; and $41.90 \%(\mathrm{w} / \mathrm{w})\left(1218-1139 \mathrm{~cm}^{-1}\right.$, Phe/Trp/Tyr C-H/C-N/C- ${ }_{6} \mathrm{H}_{5}$ vibrations). The data speak to the power of FT-IR spectroscopy as a noninvasive tool to diagnose tissue disorders such as skin, liver, kidney or any other type that would require a noninvasive tool like FT-IR, to prevent further damage during the diagnosis. These results also demonstrate an age-mediated decrease of skin-GAG content, and GAG- $N$-acetylation, in addition to protein composition concentration increments.
\end{abstract}

Keywords: Infrared Spectroscopy; Glycosaminoglycans; Skin; Age

\section{INTRODUCTION}

Infrared (IR) spectroscopy is a useful technique to identify organic, functional groups [1]. Monosaccharides, homopolysaccharides, glycosaminoglycans (GAG's) and amino acids have been characterized, using IR spectros- copy [2-4]. This technique has also been employed successfully in the analysis of age-mediated GAG alterations [5], elucidation of protein secondary structure [6], and protein conformational changes during reaction $[7,8]$. Its value in determining relative hydration states of hyaluronic acid (hyaluronan, HA) and chondroitin sulfate have been demonstrated [9]. Different types of cells may be characterized using FT-IR spectroscopy [10], and various pathologic tissues may be classified [11].

Specifically, FT-IR has been used to investigate the following cases: Examination of the stratum corneum barrier function in vivo [12]; detection of conformational changes during differential apoptosis of HL60 cells [13]; and monitoring their apoptosis progress [14]. Evidence of proton wires created by proton radicals of the $\mathrm{O}-\mathrm{H} \cdots \mathrm{O}$ bond group, with at least four other $\mathrm{O}-\mathrm{H} \cdots \mathrm{O}$ groups on either side of this chain, can act as an electrical wire to separate a positive charge [15]. Finally, the addition of a ${ }^{13} \mathrm{C}$ at a specific position of the amino acid tyrosine in a protein, changes the FT-IR vibration position of the C-C aromatic tyrosine ring to a different frequency; this facilitates detection of structural alteration when the protein folds, unfolds or forms aggregates [16]. The uses of FI-IR continue to accumulate. This paper demonstrates the reliability of FT-IR spectroscopy in the characterization of whole human skin as a function of age.

\section{MATERIALS AND METHODS}

Glycosaminoglycan standards were purified from calf ligamentum nuchae, following procedures described previously $[17,18]$. Water was filtered, passed through organic removal and mixed-bed ion-exchange cartridges (Millipore Corp., Bedford, MA), and distilled. Purified water was collected in glass, stored under nitrogen until used and tested for free amino acids, sugars, and organic compounds commonly found in water (chlorinated hydrocarbons and polyaromatic molecules). For this purpose, $2 \mathrm{~L}$ of purified water was concentrated to $200 \mu \mathrm{l}$. A 
$50 \mu \mathrm{l}$ aliquot was subjected to reaction with phenylisothiocyanate to get phenylthiohydantoin (PTH) amino acids, which were characterized and quantified using high performance liquid chromatography (HPLC) [19]; another $50 \mu \mathrm{l}$ aliquot was subjected to gas chro-matography/mass spectrometry (GC/MS), and analyzed for chlorinated hydrocarbons and polyaromatic molecules; and a third $50 \mu \mathrm{l}$ portion was subjected to silylation as described by Pierce (P.O. Box 117, Rockford, IL), and tested for silylated sugars, utilizing GC/MS. The results show that, under the conditions used, purified water was devoid of detectable amino acids, sugars or the aromatic compounds indicated above. All other reagents were of the best quality commercially available. Disposable, breast skin of Caucasian women (excised during mastectomy and certified as normal by the pathologist in service) was obtained at area hospitals within two hr from surgery and stored at $-70^{\circ} \mathrm{C}$ until used. The patients who donated the skin went to the hospital at their own will, and signed consent forms authorizing the hospital to dispose of the tissues removed from their bodies, following approved procedures, or to use them for teaching or scientific research.

\subsection{Fourier Transform Infrared Spectroscopy}

Frozen skin was allowed to warm up to room temperature and scanned on the epidermal side using a Perkin Elmer Spectrum 1000 FT-IR spectrophotometer equipped with Spectrum software and $\mathrm{LiTaO}_{3}$ detector. Just prior to use, the instrument was calibrated with compounds of known IR bands; the energy was adjusted to the same level before each run, and known standards were scanned periodically to ascertain band position. Spectra from standard goat/anti-rabbit IgG were obtained in 250 scans in triplicate at a resolution of $4.0 \mathrm{~cm}^{-1}$, and at sampling intervals of $1.0 \mathrm{~cm}^{-1}$ at room temperature, using solid $\mathrm{KBr}$ blanks. The Amide I band of this protein at 1650 - 1645 $\mathrm{cm}^{-1}$ was quantified and used as sensitivity calibration; its area did not deviate from $\pm 2.0 \%$ from the assigned value.

Whole, Caucasian, female breast skin of varying ages was then scanned under the conditions indicated above. The 250 FT-IR scans were selected after preliminary experiments demonstrated that spectra collected, utilizing these conditions, had a higher degree of reproducibility when compared to spectra collected in just a few scans. Namely, band areas were more prominent and symmetric; triplicates of spectra collected in 250 scans yielded more reproducible data than 8 or 10 spectra collected in a few scans; and the signal to noise ratio was significantly reduced.

\subsection{Standard Curve Generation}

Highly purified dermatan sulfate (DS) of calf liga- mentum nuchae was dissolved in water at a concentration of $1 \mathrm{mg} / \mathrm{ml}$. Samples containing 2 to $20 \mu \mathrm{g}$ of DS, $50 \mathrm{mg}$ of FT-IR grade $\mathrm{KBr}$ and water to a total volume of $150 \mu \mathrm{l}$ were lyophilized to dryness. The control contained $\mathrm{KBr}(50 \mathrm{mg})$ and water $(150 \mu \mathrm{l})$. The dry material was triturated thoroughly, and subjected to FT-IR spectroscopy as described above. DS concentrations between two and seven $\mu \mathrm{g}$ produced linear absorbance curves. Goat anti-rabbit IgG, D-GlcA, D-GalNAc, D-GlcNAc, and L-Phe were also employed to generate standard curves, under the same conditions, and thus confirm the DS bands.

\subsection{Chemometrics}

Fourier-transform-IR spectra collected in \% transmittance were converted to absorbance and normalized, utilizing Spectrum, the software provided by Perkin Elmer, Inc. for the IR spectrophotometer employed. Baseline correction, spectra smoothing, optimization, and area band integration were carried out using the same software. This is a good program that comes with that FT-IR. It provides the basis to get the area required, and the means to convert bands into their respective areas bands. Band areas on the skin spectra were then identified, using protein (goat anti-rabbit IgG) and DS FT-IR standard curves, using the corresponding functional groups. Band identity was also corroborated using the free sugars, and amino acids listed in the following paragraph. The averages of triplicate spectra from three different skins of every age group are reported here.

\section{RESULTS AND DISCUSSION}

Typical FT-IR spectral patterns of whole, Caucasian female, breast skin at $36 \pm 2.87$ and $78 \pm 1.25$ years appear in Figure 1. Except for band intensities, these spectra were the same for all the skins analyzed, and displayed bands characteristic of GAG's, proteins, DNA and phospholipids (among others). The bands were quantified on standard curves of DS functional groups, such as those shown in Figures 2 and 3. Although a standard curve was developed for every DS functional group detected, only two of them are shown (Figures 2 and 3). The data were corroborated using standard curves of goat anti-rabbit IgG, free D-GlcA, D-GalNAc, D-GlcNAc and L-Phe (not shown).

The FT-IR spectroscopy band in the $1738-1646 \mathrm{~cm}^{-1}$ region originates from: the $\mathrm{C}=\mathrm{O}$ stretch of monosubstituted amides like those found in $N$-acetylated GAG's [3], protein backbone (Protein Amide I) [6], ceramides [20], phospholipid esters [21] and the $-\mathrm{COOH}$ asymmetric vibrations [1]. Figure 2 shows the standard curve of the DS band in the $1738-1646 \mathrm{~cm}^{-1}$ region that was used to 


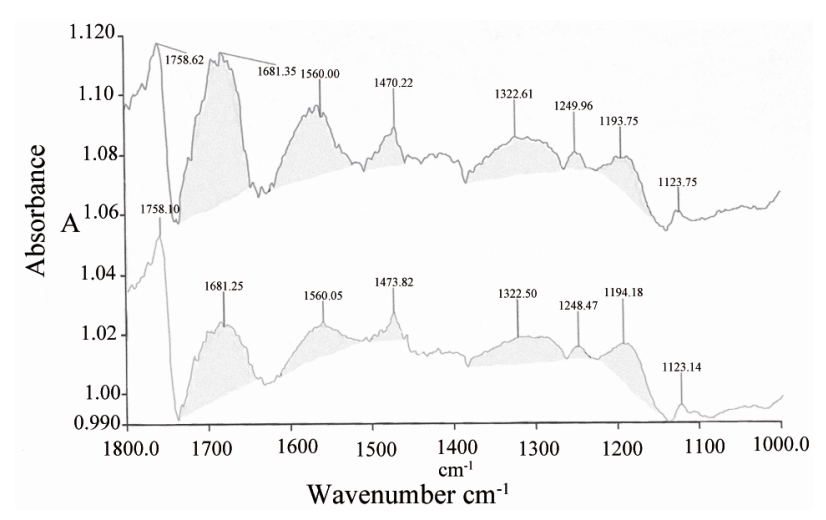

Figure 1. Typical FT-IR Spectra of whole Caucasian female breast skin. A, at $36 \pm 2.87$ years. B, at $78 \pm 1.25$ years. Spectra were collected in 250 scans in triplicate, utilizing skin from three different subjects of every age-group. Shaded, band areas were quantified on standard curves of DS functional groups. See the text for additional information.

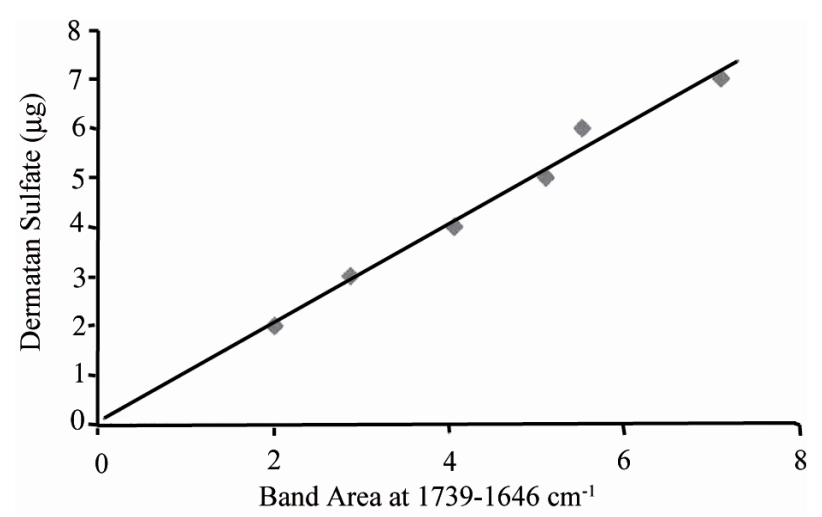

Figure 2. Standard curve of the FT-IR absorbance band area in the $1738-1646 \mathrm{~cm}^{-1}$ region of the DS spectra. Refer to the text for additional information.

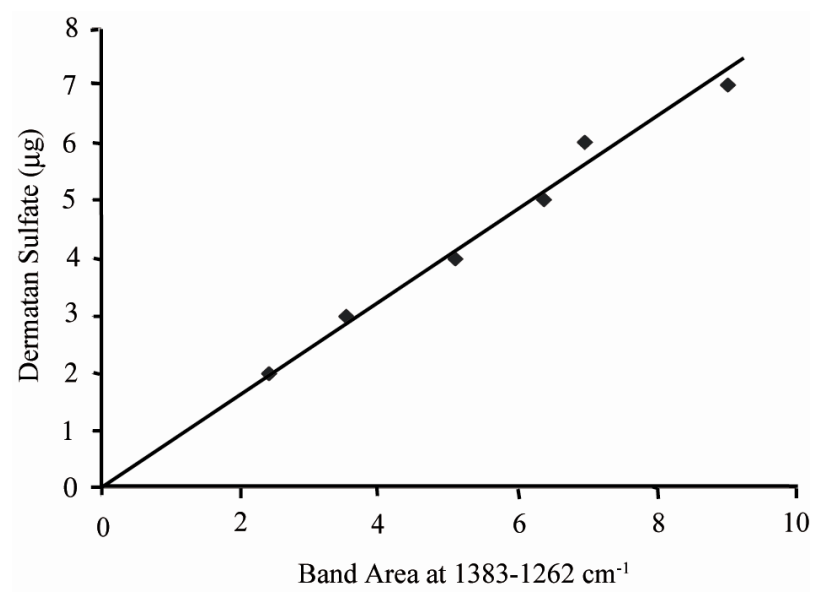

Figure 3. Standard curve of the FT-IR absorbance band area in the $1383-1262 \mathrm{~cm}^{-1}$ region of the DS spectra. See the text for more details. quantify the corresponding FT-IR bands on the spectra of human skin (Figure 1). The area of this band decreased by $35.60 \%(\mathrm{w} / \mathrm{w})$ in the older group (Table 1). Such band is made out of contributions from molecules known to increase with age like proteins [22], and from reactive carbonyl compounds that are believed to cause "the carbonyl stress" [23], minus reductions from molecules that decreased, such as GAG- $N$-acetyl groups [5, 18] ceramides [20], and phospholipids [21]. The $35.60 \%$ (w/w) decrease of band intensity at $1738-1646 \mathrm{~cm}^{-1}$ in the older group, indicates that there were more losses than gains in the number of molecules containing functional groups that absorb IR light in this region.

Because of the various positive and negative contributions to band intensity in the $1738-1646 \mathrm{~cm}^{-1}$ region $(\mathrm{C}=\mathrm{O}$ stretch) described above, the degree of age-mediated GAG- $N$-deacetylation was calculated utilizing the FT-IR spectroscopy band in the $1383-1262$ $\mathrm{cm}^{-1}$ domain that is more specific for $\mathrm{N}$-acetyl moieties (Figure 3). This band is known to originate from $\mathrm{C}-\mathrm{H}$ and $\mathrm{C}-\mathrm{C}-\mathrm{H}$ vibrational modes of methyl groups in monosubstituted amides (as in GAG's) coupled to carbohydrate $\mathrm{C}-\mathrm{C}-\mathrm{H}, \mathrm{O}-\mathrm{C}-\mathrm{H}$ and $\mathrm{C}-\mathrm{O}-\mathrm{H}$ vibrations ${ }^{3}$. Its intensity decreased by $32.00 \%(\mathrm{w} / \mathrm{w})$ in the skin spectra of the $78 \pm 1.25$ - year-olds (Table 1). These results suggest an age-mediated $N$-deacetylation of GAG's, and confirm previous data obtained utilizing purified molecules $[5,18]$.

The $34.37 \%(\mathrm{w} / \mathrm{w})$ reduction of band intensity at 1259 - $1223 \mathrm{~cm}^{-1}$ (Table 1) in the older group suggests a loss of DNA as the skin ages, since this band may arise from the $\mathrm{P}=\mathrm{O}$ stretch of phosphates $\left(\mathrm{PO}_{4}{ }^{2-}\right)$ as in nucleic acids that are known to decrease with aging, in particular mitochondrial DNA [24,25]. Stretching vibrations of the S $=\mathrm{O}$ bond of sulfates $\left(\mathrm{SO}_{4}{ }^{2-}\right)$ and sulfonates $\left(\mathrm{SO}_{3}{ }^{-}\right)$(as in GAG's) also appear in the latter region, but previous data obtained using purified molecules indicate that GAG sulfate composition is not significantly affected during aging $[5,18]$.

The areas calculated for every group was estimated on the basis of standard curves generated from groups originating from goat anti-rabbit IgG and from the corresponding DS FT-IR bands. These data show that in whole Caucasian female breast skin, GAG concentration and degree of GAG- $N$-acetylation decreased with aging, while protein content increased. Although the actual numbers obtained in this study are not the same as the ones reported previously $[5,18,26]$, these data demonstrate an age-related decrease in GAG concentration and GAG- $N$-acetylation, and a significant increment in protein content. These results speak to the power of FT-IR spectroscopy as a noninvasive tool to diagnose tissue disorders such as skin, liver, kidney or any other type 
Table 1. Quantitation of skin FT-IR spectroscopy absorbance bands.

\begin{tabular}{|c|c|c|c|c|}
\hline $\begin{array}{l}\text { Age } \\
\text { (Years) }\end{array}$ & Functional Group & $\begin{array}{l}\text { Wavenumber } \\
\quad\left(\mathrm{cm}^{-1}\right)\end{array}$ & $\begin{array}{l}\text { Band Area } \\
\quad(\mu \mathrm{g})\end{array}$ & $\begin{array}{l}\text { Change } \\
(\%)\end{array}$ \\
\hline $36 \pm 2.87$ & ${ }^{\mathrm{a}} \mathrm{S}=\mathrm{O}$ and $\mathrm{P}=\mathrm{O}$ stretch vibes & $1259-1223$ & $0.11 \pm 0.02$ & \\
\hline $78 \pm 1.25$ & ${ }^{\mathrm{a}} \mathrm{S}=\mathrm{O}$ and $\mathrm{P}=\mathrm{O}$ & $1259-1223$ & $0.07 \pm 0.02$ & $34.37 \downarrow$ \\
\hline $36 \pm 2.87$ & $\begin{array}{l}\text { bmethyl C-H/C-C-H \& C-C-H, } \\
\text { 0-C-H \& C-O-H of CHO's }\end{array}$ & $1383-1262$ & $1.63 \pm 0.15$ & \\
\hline $78 \pm 1.25$ & & $1383-1262$ & $1.11 \pm 0.09$ & $32.00 \downarrow$ \\
\hline $36 \pm 2.87$ & $\begin{array}{c}{ }^{\mathrm{c}} \mathrm{C}=\mathrm{O}+\text { Asym }-\mathrm{COOH} \text { stretch } \\
\text { Protein Amide I }\end{array}$ & $1738-1646$ & $5.49 \pm 0.77$ & \\
\hline $78 \pm 1.25$ & & $1738-1646$ & $3.53 \pm 0.47$ & $35.60 \downarrow$ \\
\hline $36 \pm 2.87$ & $\begin{array}{l}\text { Phe, Trp, Tyr C=C-vibes } \\
\text { Protein Amide II }\end{array}$ & $1636-1523$ & $1.80 \pm 0.32$ & \\
\hline $78 \pm 1.25$ & & $1636-1523$ & $0.66 \pm 0.11$ & $63.32 \uparrow$ \\
\hline $\begin{array}{l}36 \pm 2.87 \\
78 \pm 1.25\end{array}$ & Protein $\delta$ - $\left(\mathrm{CH}_{2}\right),\left(\mathrm{CH}_{3}\right)$-vibes & $\begin{array}{l}1511-1457 \\
1511-1457\end{array}$ & $\begin{array}{l}0.455 \pm 0.02 \\
0.624 \pm 0.09\end{array}$ & $27.02 \uparrow$ \\
\hline $36 \pm 2.87$ & $\begin{array}{l}\text { C-H, C-N; Phe, Trp, Tyr } \\
\text { C- } \mathrm{C}_{6} \mathrm{H}_{5} \text {-vibes }\end{array}$ & $1218-1139$ & $0.820 \pm 0.14$ & \\
\hline $78 \pm 1.25$ & & $1218-1139$ & $1.410 \pm 0.11$ & $41.90 \uparrow$ \\
\hline
\end{tabular}

${ }^{\mathrm{a}} \mathrm{S}=\mathrm{O}$ stretch of sulfates $\left(\mathrm{SO}_{4}{ }^{2-}\right)$ and sulfonates $\left(\mathrm{SO}_{3}{ }^{-}\right)$as in $\mathrm{GAG}$ 's, and $\mathrm{P}=\mathrm{O}$ stretch of $\mathrm{PO}_{4}{ }^{2-}$ as in DNA. ${ }^{\mathrm{b}} \mathrm{CH}_{3}$ of monosubstituted amides, ${ }^{\mathrm{c}}$ acetamido group of GAG's, and phospholipid esters. Absorbance band areas of triplicate spectra from three different skins of every age-group were used to determine the corresponding concentrations, using DS standard curves; the averages are shown. See the test for more information. $\downarrow$, decrease; $\uparrow$, increase.

that would require a noninvasive tool like FT-IR, to prevent further damage during the diagnosis.

\section{ACKNOWLEDGEMENTS}

This work was supported by Purdue University Calumet Scholarly Research Release Award and by the NSF NS-FILIP DUE 9650816 grant to M. O. Longas.

\section{REFERENCES}

[1] Solomons, T.W. and Fryhle, C.B. (2004) Oganic Chemistry. 8th Edition, John Wiley \& Sons Inc., New York, 7993.

[2] Orr, S.F.D. (1954) Infra-red spectroscopic studies of some polysaccharides. Biochimica et Biophysica Acta, 14, 173-181. doi:10.1016/0006-3002(54)90156-0

[3] Cael, J.J., Isaac, D., Blackwell, H.J., Koenig, J.L., Atkins, E.D.T., Sheehan, J.K. (1976) Polarized infrared spectra of crystalline glycosaminoglycans. Carbohydrate Research, 50, 169-179. doi:10.1016/S0008-6215(00)83848-3

[4] Venyaminov, Y. and Kalnin, N.N. (1990) Quantitative IR spectrophotometry of peptide compounds in water $\left(\mathrm{H}_{2} \mathrm{O}\right)$ solutions. I. Spectral parameters of amino acid residue absorption bands. Biopolymers, 30, 1243-1257. doi:10.1002/bip.360301309

[5] Longas, M.O., Russell, C.S. and He, X-Y. (1986) Biochimica et Biophysica Acta, 884, 265-269.

[6] Venyaminov, Y. and Kalnin, N.N. (1990) Quantitative IR spectrophotometry of peptide compounds in water (H2O) solutions. II. Amide absorption bands of polypeptides and fibrous proteins in $\alpha-, \beta-$, and random coil con-formations. Biopolymers, 30, 1259-1271.

\section{doi:10.1002/bip.360301310}

[7] Kötting, C. and Gerwert, K. (2005) Proteins in Action Monitored by Time-Resolved FTIR Spectroscopy. Chem Phys Chem, 6, 881-888. doi:10.1002/cphc.200400504

[8] Pinakoulaki, E., Koutsoupakis, C., Stavrakis, S., Aggelaki, M., Gambaro, G., Papadopoulos, V. and Daskalakis, C., Varotsis, (2005) Structural dynamics of heme-copper oxidases and nitric oxide reductases: Time-resolved stepscan Fourier transform infrared and time-resolved resonance Raman studies. Journal of Raman Spectroscopy, 36, 337-349. doi: $10.1002 /$ jrs. 1313

[9] Servaty, R., Schiller, J., Binmdier, H. and Arnold, K. (2001) Hydration of polymeric components of cartilage - an infrared spectroscopic study on hyaluronic acid and chondroitin sulfate. International Journal of Biological Macromolecules, 28, 121-127. doi:10.1016/S0141-8130(00)00161-6

[10] Gaigneaux, A., Ruysschaert, J.M. and Goormaghtigh, E. (2002) Infrared spectroscopy as a tool for discrimination between sensitive and multiresistant K562 cells. Euro-pean Journal of Biochemistry, 269, 1968-1973. doi:10.1046/j.1432-1033.2002.02841.x

[11] Crupi, V., Venuti, V. and Majolino, D. (2004) Spectroscopy, 19, 22-30 \& 42

[12] Bommannan, D., Potts, R.O. and Guy, R.H. The Society for Investigative Dermatology, Inc., 1990, 95, 403-408.

[13] Zhou, J., Wang, Z., Sun, S., Liu, M. and Zhang, H. (2001) A rapid method for detecting conformational changes during differentiation and apoptosis of HL60 cells by Fourier-transform infrared spectroscopy. Biotechnology and Applied Biochemistry, 33, 127-132. doi:10.1042/BA20000074

[14] Gasparri F. and Muzio M. (2003) Monitoring of 
apoptosis of HL60 cells by Fourier-transform infrared spectroscopy. Biochemical Journal, 369, 239-248. doi:10.1042/BJ20021021

[15] Stoyanov, E.S., Stoyankova, I.V. and Reed C.A. (2008) IR Spectroscopic Properties of $\mathrm{H}(\mathrm{MeOH})_{n}{ }^{+}$Clusters in the Liquid Phase: Evidence for a Proton Wire. European Journal of Chemistry, 14, 3596-3604. doi:10.1002/chem.200701746

[16] Beyermannn, M., Tremmel, S., Oschkinat, H., Bienert, M. and Hainz, F. (2005) spectroscopyNOW.com

[17] Meyer, K. (1958) Fed Proc. 17, 1075-1077.

[18] Longas, M.O., Russell, C.S., He, X-Y. (1987) Evidence for structural changes in dermatan sulfate and hyaluronic acid with aging. Carbohydrate Research, 159, 127-136. doi:10.1016/S0008-6215(00)90010-7

[19] Tsunasawa, S., Kondo, J. and Sakiyama, F.J. (1985) Biochemistry, 97, 701-704.

[20] Coderch, L., López, O., Maza, A. and Parra, J.L. (2003) Ceramides and Skin, 4,107-129.

[21] Schroeder, F., Goetz, I. and Roberts, E. (1984) Age-related alterations in cultured human fibroblast membrane structure and function. Mechanisms of Ageing

\section{Abbreviations}

DS: dermatan sulphate;

DNA: deoxyribonucleic acid;

FT-IR: Fourier transform infrared; and Development, 25, 365-389. doi:10.1016/0047-6374(84)90010-1

[22] Gniadecka, M.,Nielsen, O.F., Christensen, D.H. and Wulf, H. (1998) Structure of water, proteins, and lipids in intact human skin, hair, and nail. Journal of Investigative Dermatology, 110, 393-398. doi:10.1046/j.1523-1747.1998.00146.x

[23] Schleicher, E.D., Bierhaus, A., Häring, H-U., Nawroth, P.P. and Lehmann, R. (2001) In: D'Angelo, A., Favaro, S. and Gambaro, G. Eds., Chemistry and Pathology of Advanced Glycation End Products, Advanced Glycation End Products in Nephrology, Contrib. Nephrol., Basel, 139, 1-9.

[24] Proksch, E., Feingold, K.R., Man, M.Q. and Elias, P.M. (1991) Journal of Clinical Investigation, 87, 1668-1673. doi:10.1172/JCI115183

[25] Alexeyev, M.F., LeDoux, S.P. and Wilson, G.L. (2004) Barrier function regulates epidermal DNA synthesis. Clinical Science, 107, 355-364. doi:10.1042/CS20040148

[26] Rocquet, C. and Bonté, F. (2002) Acta Dermatovenerologica Alpina, Pannonica Et Adriatica, 11, 1-59.
GC/MS: gas chromatography/mass spectrometry;

GAG: glycosaminoglycan;

HA: hyaluronic acid, hyaluronan 